\title{
Percent Predicted Forced Expiratory Flow at 25-75 Percent
}

National Cancer Institute

\section{Source}

National Cancer Institute. Percent Predicted Forced Expiratory Flow at 25-75 Percent.

NCl Thesaurus. Code C119546.

The mean forced expiratory flow rate at $25-75 \%$ of the forced vital capacity as a proportion of the predicted normal value. 